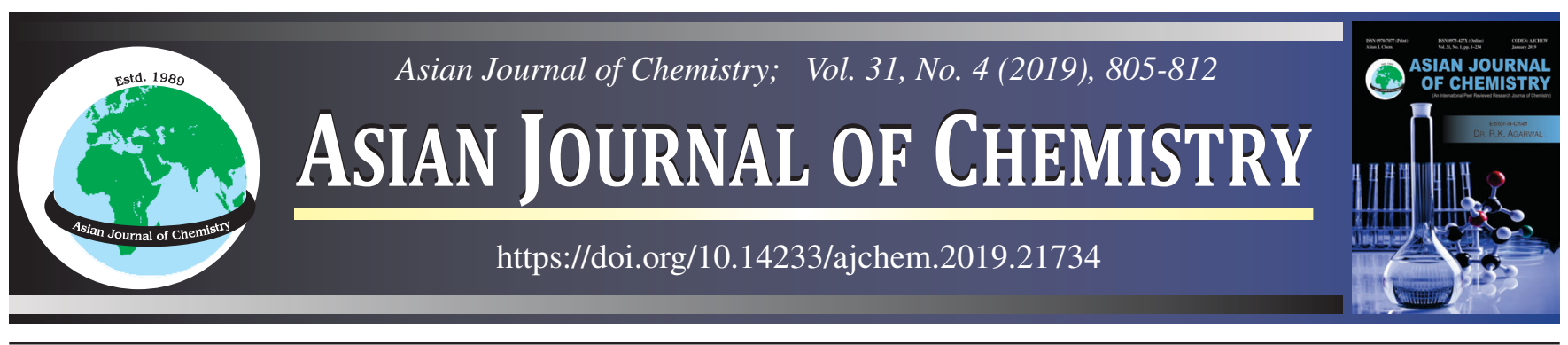

\title{
Antarvedisides A-B from Manglicolous Lichen Dirinaria consimilis (Stirton) and their Pharmacological Profile
}

\author{
Vinay Bharadwaj Tatipamula ${ }^{1, \oplus}$, Girija Sastry Vedula ${ }^{1, *}, \bullet$ and A.V.S. Sastry ${ }^{2}$
}

${ }^{1}$ Pharmaceutical Chemistry Department, AU College of Pharmaceutical Sciences, Andhra University, Visakhapatnam-530003, India ${ }^{2}$ Pharmacology Department, Maharajah's College of Pharmacy, Phoolbaugh, Vizianagram-535002, India

*Corresponding author: Tel: +91 891 2844926; E-mail: vgirijasastry@yahoo.co.in

Received: 1 October 2018;

Accepted: 24 December 2018;

Published online: 27 February 2019;

AJC-19289

\begin{abstract}
The chemical examination of acetone extract of Dirinaria consimilis resulted in isolation of six depsides of which two novel metabolites namely antarvediside A (1) and antarvediside B (2) and four known metabolites i.e. sekikaic acid (3), atranorin (4), divaricatic acid (5) and 2'-O-methyl divaricatic acid (6). From the pharmacological screening of the isolates (1-6), it was found that $\mathbf{1}$ and $\mathbf{2}$ exhibited better inhibition of ABTS and superoxide free radicals than that of the standard and compound $\mathbf{4}$ showed significant inhibition of protein denaturation with $\mathrm{IC}_{50}$ value of $390 \mathrm{mg} / \mathrm{mL}$ with respect to indomethacin with $110 \mathrm{mg} / \mathrm{mL}$. From the SRB assay results, the better $\mathrm{IC}_{50}$ values was determined by compound 2 of $10.5,11.50$ and $12.50 \mu \mathrm{g} / \mathrm{mL}$ on HeLa, MCF-7 and FADU cancer cell lines, respectively. Thus, the outcomes revealed that the $D$. consimilis is a new source to treat free radicals, inflammation and cancer.
\end{abstract}

Keywords: Antioxidant, Protein denaturation, Inflammation, Cancer, Sulforhodamine B assay.

\section{INTRODUCTION}

Dirinaria consimilis (Stirton) D.D. Awasthi is a foliose lichen belongs to the Dirinaria genus and the chemical tests of thalli of $D$. consimilis depicted the existence of mainly sekikaic acid and traces of $3 \beta$-acetoxyhopane-1 $\beta, 22$-diol, 4- $O$-demethylsekikaic acid, atranorin, chloroatranorin, homosekikaic acid, whereas the thallus of other species of Dirinaria (D. applanata) contains atranorin and divaricatic acid. In 2009, a non-reducing polyketide synthase gene have been isolated and characterized from $D$. applanata [1]. The LC-HRESIMS analysis of methanolic extract of $D$. applanata noticed to have ellagic acid 3,3'-di- $O$-methyl ether, 5,5'-dehydrodiferulic acid, 3,3',4-tri- $O$-methylellagic acid, 5'-methoxydehydrodiconiferyl alcohol, gaigrandin, terpecurcumin Q, ergosteryl acetate, taxuspine $\mathrm{C}$ and dichrostachine $\mathrm{F}$ [2].

In 2013, studies related to polycylic aromatic hydrocarbon analysis of Dirinaria picta revealed the presence of naphthalene, acenaphthylene, acenaphthene, anthracene, phenanthrene, fluoranthene, pyrene, benzo anthracene and chrysene [3]. The metabolic profile using GC-MS, LC-QTOF and MS/MS analysis of D. picta showed existence of 5-methyluridine, ethyl syringate, $\delta$-guanidinovaleric acid, orsellinic acid, ethyl ester, 3,4-dihydroxyphenylvaleric acid, usnic acid, ethyl everninate, 2-O-methylatranorin, carbamic acid, propionic acid, glycolic acid, 1,3-hydroxy-3-methylglutaric acid, ribonic acid, gluconic acid, $\beta$-amyrone and various sugar and amino acid moieties [4].

Earlier, the methanolic extract of D. applanata exhibited good antioxidant, antimicrobial, cytotoxic and larvicidal effects with good content of phenols [1,2], while dichloromethane and methanolic extracts of $D$. confluens showed only larvicidal and antimicrobial activities [3]. In 2016, the pharmacological studies on $D$. aspera showed activity against B16-F10 melanoma and UACC-62 cells and 3T3 normal cells [4]. In 2015, the biological studies of methanolic extract from the $D$. consimilis showed significant inhibitory activities against different bacterial and fungal stains [5]. In 2016, the in vitro anticaries activity of ethanolic extract of $D$. consimilis showed moderate activity against Streptococcus mutans [5]. Earlier, our group has reported the anti-inflammatory and cytotoxicity studies of different extracts of $D$. consimilis [6,7].

Keeping in mind of the aforementioned the chemical and biological profile of D. consimilis as well as Dirinaria genus,

This is an open access journal, and articles are distributed under the terms of the Creative Commons Attribution-NonCommercial-ShareAlike 4.0 (CC BY-NC-SA 4.0) International License which allows readers to freely read, download, copy, distribute, print, search, or link to the full texts of its articles and to use them for any other lawful non-commercial purpose as long as the original source is duly acknowledged. 
we have established complete chemical and pharmacological profile of manglicolous lichen (lichen associated particularly on mangrove plants [8] D. consimilis.

The structures of novel and known depsides from Dirinaria consimilis are shown in Fig. 1.

\section{EXPERIMENTAL}

The specimens of manglicolous lichen Dirinaria consimilis (Stirton) was collected on the bark of mangrove plant Excoecaria agallocha from Vainateya Island, Godavari estuary, Andhra Pradesh, India (16 $44^{\circ} 48^{\prime \prime} \mathrm{N}$ and $81^{\circ} 98^{\prime} 19^{\prime \prime} \mathrm{E}$ with 0 m elevation) in February, 2015 [8]. This species were authenticated by Dr. D.K. Upreti, CSIR-National Botanical Research Institute (NBRI), Lucknow and deposited at Lichen herbarium, CSIR-NBRI, Lucknow, India with accession numbers 15-027173.

Extraction and isolation: The lichen specimen were gently collected from the bark of E. agallocha and shade dried. The dried lichen material $(50 \mathrm{~g})$ was powdered, suspended in acetone for 1 week and evaporated under reduced pressure and dried over anhydrous sodium sulphate and concentrated to obtain dry acetone extract of $D$. consimilis (DC-Ac, $1.44 \mathrm{~g}$ ). The DCAc was subjected to column chromatography by using silica gel (\#230-400) resulted in four bioactive fractions. Fraction I (100 mg) was obtained as a pale pink colour solid and rechromatographed over silica gel (\#230-400) using hexane and dichloromethane, which yields compound $\mathbf{1}(8 \mathrm{mg})$ as white solid and compound $\mathbf{2}(19 \mathrm{mg})$ as a pale pink colour substance, respectively. Fraction II (90 mg) was obtained as a white solid, which on purification by column chromatography (\#230-400) using DCM in ethyl acetate as eluent to obtain compound $\mathbf{3}$ $(69 \mathrm{mg})$ as white solid. Fraction III $(281 \mathrm{mg})$ was white solid material is subjected to column chromatography (\#230-400) using DCM in ethyl acetate as eluent to obtain compound 4 (90 $\mathrm{mg})$ as colourless needles and compound $\mathbf{5}(162 \mathrm{mg}$ ) as a white solid, respectively. Fraction IV (20 mg) was white solid material is subjected to column chromatography (\#230-400) using hexane in ethyl acetate as eluent to obtain compound 6 (11 mg) as colourless solid.
Antarvediside A (1): $\mathrm{C}_{38} \mathrm{H}_{34} \mathrm{O}_{14}$; Yield: $8 \mathrm{mg}(0.56 \%)$; $\mathrm{R}_{\mathrm{f}}: 0.7$ (Hexane:DCM, 9:1); m.p.: 191-192 ${ }^{\circ} \mathrm{C}$; IR (KBr, $v_{\max }$, $\mathrm{cm}^{-1}$ ): 576.98, 702.11, 824.89, 1023.35, 1083.37, 1204.44, $1273.79,1356.55,1395.78,1456.68,1519.46,1646.32$, 2928.97, 3426.57, 3747.67, 3858.20; UV (Ethanol) $\lambda_{\max }(\log$ ع) $222 \mathrm{~nm}$; CHNS analysis: anal. C-63.76, H-4.82 (\%), calcd. C, 63.86, H, 4.80 (\%); ESI-MS [MH] ${ }^{+} \mathrm{m} / z:$ : 715.00.

Antarvediside B (2): $\mathrm{C}_{46} \mathrm{H}_{40} \mathrm{O}_{18}$; Yield: $19 \mathrm{mg}(1.32 \%)$; $\mathrm{R}_{\mathrm{f}}$ : 0.2 (Hexane:Ethyl acetate, 7:3); m.p.: 203-204 ${ }^{\circ} \mathrm{C}$; UV (Ethanol) $\lambda_{\max }(\log \varepsilon) 219 \mathrm{~nm}$; CHNS analysis: anal. C-62.76, H-4.54 (\%), calcd. C, 62.73, H, 4.58 (\%); ESI-MS [MH] ${ }^{+} \mathrm{m} / \mathrm{z}$ : 881.21 .

Sekikaic acid (3): $\mathrm{C}_{22} \mathrm{H}_{26} \mathrm{O}_{8}$; Yield: $69 \mathrm{mg}(4.79 \%) ; \mathrm{R}_{\mathrm{f}}$ : 0.6 (DCM:Ethyl acetate, $1: 1$ ); m.p.: $220-221^{\circ} \mathrm{C}$; UV (Methanol) $\lambda_{\max }(\log \varepsilon) 219 \mathrm{~nm}$; IR $\left(\mathrm{KBr}, v_{\max }, \mathrm{cm}^{-1}\right): 596.02,660.91$, 727.63, 756.03, 798.43, 861.89, 894.62, 953.06, 1018.59, 1039.09, 1138.46, 1203.15, 1241.04, 1283.58, 1311.71, 1353.07, 1425.20, 1458.95, 1610.97, 1644.68, 1667.87, 2588.20, 2874.03, 2956.55, 3440.69. ${ }^{1} \mathrm{H}$ NMR $\left(\mathrm{CDCl}_{3}, 400\right.$ MHz) $\delta$ 0.97-1.05 (m, 6H, 2CH $\mathrm{CH}_{3}, 1.69-1.72\left(\mathrm{~m}, 4 \mathrm{H}, 2 \mathrm{CH}_{2}\right)$, 2.95-3.04 (m, 4H, $\left.2 \mathrm{CH}_{2}\right), 3.85\left(\mathrm{~s}, 3 \mathrm{H}, 1 \mathrm{OCH}_{3}\right), 3.91(\mathrm{~s}, 3 \mathrm{H}$, $\left.1 \mathrm{OCH}_{3}\right), 6.40-6.42$ (dd, $\left.J=4,8 \mathrm{~Hz}, 2 \mathrm{H}, 2 \mathrm{CH}_{\mathrm{ar}}\right), 6.66-6.67$ (d, $\left.J=3.2 \mathrm{~Hz}, 1 \mathrm{H}, 1 \mathrm{CH}_{\mathrm{ar}}\right), 6.77-6.78\left(\mathrm{~d}, J=3.8 \mathrm{~Hz}, 1 \mathrm{H}, 1 \mathrm{CH}_{\mathrm{ar}}\right)$, 10.39 (s, $1 \mathrm{H}, 1 \mathrm{OH}), 11.40(\mathrm{~s}, 2 \mathrm{H}, 2 \mathrm{OH}) ;{ }^{13} \mathrm{C} \mathrm{NMR}\left(\mathrm{CDCl}_{3}\right.$, $400 \mathrm{MHz}) \delta 14.18,14.23,24.84,25.28,38.53,39.18,55.43$, $99.03,103.60,108.55,111.58,116.22,148.11,149.53,154.92$, 164.88, 165.33, 166.60, 169.40, 174.34; CHNS analysis: anal. C-63.16, H-6.24 (\%), calcd. C, 63.15, H, 6.26 (\%); ESI-MS $[\mathrm{MH}]^{+} \mathrm{m} / \mathrm{z}: 419.33$.

Atranorin (4): $\mathrm{C}_{19} \mathrm{H}_{18} \mathrm{O}_{8}$; Yield: $90 \mathrm{mg}(6.25 \%)$; $\mathrm{R}_{\mathrm{f}}: 0.4$ (DCM:Ethyl acetate, 1:1); m.p.: 196-197 ${ }^{\circ} \mathrm{C}$; UV (Methanol) $\lambda_{\max }(\log \varepsilon) 210 \mathrm{~nm} ;{ }^{1} \mathrm{H}$ NMR $\left(\mathrm{CDCl}_{3}, 400 \mathrm{MHz}\right) \delta 2.12(\mathrm{~s}$, $\left.3 \mathrm{H}, 1 \mathrm{CH}_{3}\right), 2.57\left(\mathrm{~s}, 3 \mathrm{H}, 1 \mathrm{CH}_{3}\right), 2.71\left(\mathrm{~s}, 3 \mathrm{H}, 1 \mathrm{CH}_{3}\right), 4.01(\mathrm{~s}$, $\left.3 \mathrm{H}, 1 \mathrm{OCH}_{3}\right), 6.43\left(\mathrm{~s}, 1 \mathrm{H}, \mathrm{CH}_{\mathrm{ar}}\right), 6.54\left(\mathrm{~s}, 1 \mathrm{H}, \mathrm{CH}_{\mathrm{ar}}\right), 10.39$ (s, $1 \mathrm{H}, 1 \mathrm{CHO}), 11.97(\mathrm{~s}, 1 \mathrm{H}, 1 \mathrm{OH}), 12.52(\mathrm{~s}, 1 \mathrm{H}, 1 \mathrm{OH}), 12.58$ (s, $1 \mathrm{H}, 1 \mathrm{OH}) ;{ }^{13} \mathrm{C} \mathrm{NMR}\left(\mathrm{CDCl}_{3}, 400 \mathrm{MHz}\right) \delta 9.37,24.02$, 25.58, 52.34, 102.85, 108.56, 110.27, 112.87, 116.02, 116.08, $139.88,152.00,152.44,162.89,167.50,169.10,169.71$,

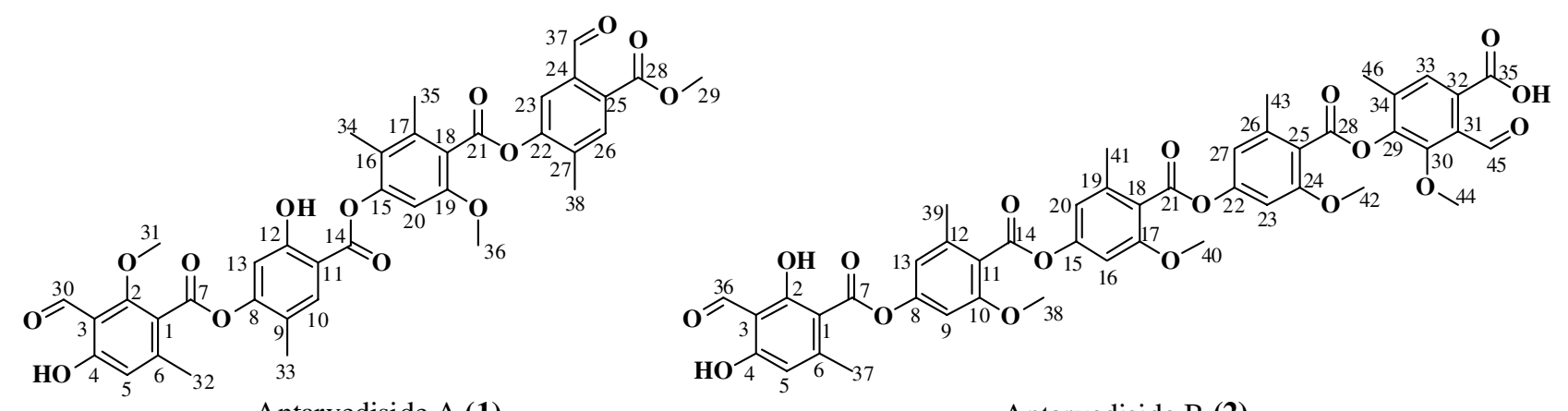

Antarvediside A (1)

Antarvediside B (2)<smiles>CCCc1cc(OC)cc(O)c1C(=O)Oc1c(OC)cc(CCC)c(C(=O)O)c1OCC</smiles>

Sekikaic acid (3)<smiles>CCCc1cc(OC)cc(O)c1C(=O)Oc1cc(CCC)c(C(=O)O)c(OC)c1</smiles>

Atranorin (4)<smiles>CCCc1cc(OC)cc(O)c1C(=O)Oc1cc(CCC)c(C(=O)O)c(OC)c1</smiles>

2'-O-Methyldivaricatic acid (6)

Fig. 1. Structures of novel and known depsides from Dirinaria consimilis 
172.21, 193.36; CHNS analysis: anal. C-60.76, H-4.74 (\%), calcd. C, 60.96, H, 4.85 (\%); ESI-MS [MH] ${ }^{+} m / z: 375.11$.

Divaricatic acid (5): $\mathrm{C}_{21} \mathrm{H}_{24} \mathrm{O}_{7}$; Yield: $162 \mathrm{mg}(11.25 \%)$; $\mathrm{R}_{\mathrm{f}}: 0.2$ (DCM:Ethyl acetate, 1:1); m.p.: $138-139^{\circ} \mathrm{C}$; UV (Ethanol) $\lambda_{\max }(\log \varepsilon) 213 \mathrm{~nm}$; IR $\left(\mathrm{KBr}, v_{\max }, \mathrm{cm}^{-1}\right): 590.98$ 659.01, 727.03, 756.05, 798.33, 861.73, 893.24, 952.35, 1018.91, $1039.69,1077.04,1137.74,1202.80,1239.87,1283.83$, $1311.80,1352.84,1425.59,1458.56,1609.55,1645.87$, 1669.94, 2591.35, 2874.04, 2956.45, 3424.84; ${ }^{1} \mathrm{H}$ NMR $\left(\mathrm{CDCl}_{3}, 400 \mathrm{MHz}\right) \delta 0.97-1.05\left(\mathrm{~m}, 6 \mathrm{H}, 2 \mathrm{CH}_{3}\right), 1.70-1.72(\mathrm{~m}$, $\left.4 \mathrm{H}, 2 \mathrm{CH}_{2}\right), 2.96-3.04\left(\mathrm{~m}, 4 \mathrm{H}, 2 \mathrm{CH}_{2}\right), 3.85\left(\mathrm{~s}, 3 \mathrm{H}, 1 \mathrm{OCH}_{3}\right)$, 6.40-6.42 (s, 2H, 2CH $\left.\mathrm{CH}_{\mathrm{ar}}\right), 6.67\left(\mathrm{~s}, 1 \mathrm{H}, \mathrm{CH}_{\mathrm{ar}}\right), 6.78\left(\mathrm{~s}, 1 \mathrm{H}, \mathrm{CH}_{\mathrm{ar}}\right)$, $11.36(\mathrm{~s}, 2 \mathrm{H}, 2 \mathrm{OH}) ;{ }^{13} \mathrm{C} \mathrm{NMR}\left(\mathrm{CDCl}_{3}, 400 \mathrm{MHz}\right) \delta 14.19$, $14.23,24.83,25.28,38.54,39.18,55.43,99.03,103.58$, $108.50,108.99,111.59,116.27,148.11,149.62,154.98$, 164.89, 165.35, 166.61, 169.39, 174.67; CHNS analysis: anal. C-64.76, H-6.34 (\%), calcd. C, 64.94, H, 6.23 (\%); ESI-MS $[\mathrm{MH}]^{+} \mathrm{m} / \mathrm{z}: 387.00$

2'- $\boldsymbol{O}$-methyldivaricatic acid (6): $\mathrm{C}_{22} \mathrm{H}_{26} \mathrm{O}_{7}$; Yield: $11 \mathrm{mg}$ $(0.76 \%) ; \mathrm{R}_{\mathrm{f}}: 0.4$ (hexane:ethyl acetate, $\left.1: 1\right)$; m.p.: $142-143{ }^{\circ} \mathrm{C}$; UV (Ethanol) $\lambda_{\max }(\log \varepsilon) 212.5 \mathrm{~nm} ;{ }^{1} \mathrm{H}$ NMR $\left(\mathrm{CDCl}_{3}, 400\right.$ $\mathrm{MHz}) \delta$ 0.93-1.05 (m, 6H, 2CH $\mathrm{CH}_{3}, 1.66-1.80\left(\mathrm{~m}, 4 \mathrm{H}, 2 \mathrm{CH}_{2}\right)$, 2.95-3.04 (m, $\left.4 \mathrm{H}, 2 \mathrm{CH}_{2}\right), 3.85\left(\mathrm{~s}, 3 \mathrm{H}, 1 \mathrm{OCH}_{3}\right), 3.91(\mathrm{~s}, 3 \mathrm{H}$, $\left.1 \mathrm{OCH}_{3}\right), 6.40\left(\mathrm{~s}, 2 \mathrm{H}, 2 \mathrm{CH}_{\mathrm{ar}}\right), 6.46\left(\mathrm{~s}, 1 \mathrm{H}, \mathrm{CH}_{\mathrm{ar}}\right), 11.18(\mathrm{~s}, 1 \mathrm{H}$, $1 \mathrm{OH}), 11.73$ (s, $1 \mathrm{H}, 1 \mathrm{OH}) ;{ }^{13} \mathrm{C}$ NMR $\left(\mathrm{CDCl}_{3}, 400 \mathrm{MHz}\right) \delta$ $14.35,14.36,24.84,25.15,38.87,39.10,55.37,56.05,98.89$, 104.45, 104.45, 104.65, 106.48, 110.97, 124.94, 147.31, 148.73, 156.40, 156.94, 164.42, 165.55, 168.91, 175.47; CHNS analysis: anal. C-65.66, H-6.62 (\%), calcd. C, 65.66, H, 6.51 (\%); ESIMS $[\mathrm{MH}]^{+} m / z: 403.05$.

General procedure for the basic hydrolysis of compounds 1 and 2: The isolate 1 or $\mathbf{2}(2 \mathrm{mg})$ was dissolved in methanol and 2-3 drops of distilled water and $5 \mathrm{~N}$ potassium hydroxide were added to the solution. The reaction mixture was heated to reflux for $2-3 \mathrm{~h}$. The thin layer chromatography confirmed the completion of the reaction and the reaction mass was subjected to gas chromatography-mass spectrometry (GC-MS) analysis.

\section{Antioxidant activity}

DPPH assay: The 1,1-diphenyl-2-picrylhydrazyl (DPPH) assay [9] is based on the reduction of $\mathrm{DPPH}^{*}$ radical in presence of natural/synthetic antioxidant turns to non-radical DPPH (yellow coloured). Initially, $0.004 \%$ DPPH in methanol was prepared and reacted with known concentrations of the extract $(50,100,150$ and $200 \mu \mathrm{g} / \mathrm{mL})$ and pure compound/standard $(25,50,75$ and $100 \mu \mathrm{g} / \mathrm{mL})$, incubated for $30 \mathrm{~min}$ at $37{ }^{\circ} \mathrm{C}$. Then the absorbance was noted at $517 \mathrm{~nm}$ on UV-visible spectrometer and the experiment was triplicated and the obtained optical density values were converted into percentage inhibition using the percentage inhibition formula.

ABTS radical scavenging assay: All the prepared extracts was subjected to 2,2'-azino-bis(3-ethylbenzothiazoline-6sulphonic acid (ABTS) free radical scavenging assay [10]. Firstly, the stock solution was prepared by adding $7 \mathrm{mM}^{\circ} \mathrm{ABTS}^{+\bullet}$ to $2.45 \mathrm{mM}$ potassium persulfate in water at $25{ }^{\circ} \mathrm{C}$ and standardized for $16 \mathrm{~h}$. Then to each $1 \mathrm{~mL}$ of ABTS ${ }^{+\bullet}$ solution added different concentrations of extract $(50,100,150$ and $200 \mu \mathrm{g} /$ $\mathrm{mL})$ and pure compound/standard $(25,50,75$ and $100 \mu \mathrm{g} /$ $\mathrm{mL}$ ), incubated for $6 \mathrm{~min}$ and the absorbance was measured at
$750 \mathrm{~nm}$ using UV-visible spectrophotometer and the experiment was triplicated and the data was expressed as percentage inhibition.

Superoxide radical scavenging assay: In this radical method [9], the superoxide radicals generated from non-enzymatic phenazine methosulfate/nicotinamide adenine dinucleotide (PMS/NADH) reduces nitro blue tetrazolium (NBT) to a purple formazan. To $1 \mathrm{~mL}$ of reaction mixture contained $20 \mathrm{mM}$ phosphate buffer (pH 7.4), $73 \mu \mathrm{M}$ NADH, $50 \mu \mathrm{M} \mathrm{NBT}, 15 \mu \mathrm{M}$ PMS added various concentrations of extract $(50,100,150$ and 200 $\mu \mathrm{g} / \mathrm{mL}$ ) and pure compound/standard $(25,50,75$ and $100 \mu \mathrm{g} / \mathrm{mL})$ and incubated for $10 \mathrm{~min}$ at room temperature and the absorbance was noted at $562 \mathrm{~nm}$ against blank using UV-visible spectrophotometer and the experiment was triplicated and the data was data was expressed as percentage inhibition.

$$
\text { Percentage inhibition }(\%)=\frac{A_{c}-A_{s}}{A_{c}} \times 100
$$

where $\mathrm{A}_{\mathrm{c}}$ is the absorbance of the control, $\mathrm{A}_{\mathrm{s}}$ is the absorbance of sample.

A graph is plotted between concentrations of the sample and their percentage inhibition to determine the $\mathrm{IC}_{50}$ values of particular sample.

in vitro Anti-inflammatory activity: Protein denaturation method [6] was employed for the evaluation of in vitro antiinflammatory activity for all compounds and extracts in three sets and the mean \pm SD values are reported. Bovine serum albumin (BSA) protein was used in this study. The protein was solubilized to $1 \%$ concentration using sodium phosphate buffer (50 mM, pH 6.4). To $0.2 \mathrm{~mL}$ of prepared protein, 0.1 $\mathrm{mL}$ of sample dissolved in DMSO (Sample size - 0.1, 0.2, 0.4, $0.6,0.8$ and $1 \mathrm{mg} / \mathrm{mL}$ for sample) was added and final volume adjusted to $5 \mathrm{~mL}$ with buffer. Then the sample tubes are incubated at $37^{\circ} \mathrm{C}$ for $20 \mathrm{~min}$. Thereafter, the tubes are heated in steam bath at $95^{\circ} \mathrm{C}$ for $20 \mathrm{~min}$ and then cooled to room temperature. Finally, the turbidity in the cooled tubes are measured at $660 \mathrm{~nm}$ by UV-visible spectrophotometer (Model SL 210, Elico India Ltd.). The percentage inhibition of serum albumin protein denaturation was determined as follows and $\mathrm{IC}_{50}$ values were calculated by plotting concentration $v s$. percentage inhibition.

$$
\text { Percentage inhibition }(\%)=\frac{\mathrm{C}-\mathrm{S}}{\mathrm{C}} \times 100
$$

where $\mathrm{C}$ is absorbance of control, $\mathrm{S}$ is absorbance of sample.

A graph is plotted between concentrations of the sample and their percentage inhibition to determine the $\mathrm{IC}_{50}$ values of particular sample.

\section{Anticancer activity}

Cancer cell lines: MCF-7 (Breast), DLD-1 (colon), HeLa (cervical), FaDu (head \& neck), A549 (lung) and normal human mammary epithelial (NHME) cell lines were kindly provided by National Centre for Cell Science, Pune. The cancer cells were maintained in MEM media (containing $10 \%$ fetal calf serum, $5 \%$ mixture of penicillin (100 units) and streptomycin $(100 \mu \mathrm{g} / \mathrm{mL})$ in presence of $5 \%$ carbon dioxide incubator having $90 \%$ humidity at $37^{\circ} \mathrm{C}$ for $72 \mathrm{~h}$.

Cell growth medium: All the cancer cell lines were maintained in minimal essential medium (MEM) (adjusted to 10 $\%(\mathrm{v} / \mathrm{v}) \mathrm{FBS}, 1.5 \mathrm{~g} / \mathrm{mL} \mathrm{NaHCO}_{3}, 0.1 \mathrm{mM}$ MEM non-essential 
amino acids and $1 \mathrm{mM}$ sodium pyruvate). Three days prior to performing assay, the cells were washed with sterilized PBS and grown using MEM media (supplemented with $0.25 \%$ trypsin in versene-EDTA and $10 \%$ FBS) and mixed to obtain homogeneous suspension of cells. The suspension was taken in a sterilized polypropylene tube and the cell concentration in each well was determined by hematocytochameter chamber under a microscope using $0.4 \%$ trypan blue solution. The minimal seed density must be $1 \times 10^{4}$ cells per well.

Sample preparation: Initially, for all the extracts (at 100 $\mu \mathrm{g} / \mathrm{mL}$ ), compounds (at $30 \mu \mathrm{g} / \mathrm{mL}$ ) and standard (doxorubicin at $10 \mu \mathrm{g} / \mathrm{mL}$ ) were dissolved in DMSO and screened against selected cancer cell lines. The active samples i.e. more than $50 \%$ inhibition were further screened at 25, 50, 75 and 100 $\mu \mathrm{g} / \mathrm{mL}$ concentrations for extracts; $5,10,20$ and $30 \mu \mathrm{g} / \mathrm{mL}$ concentrations for pure compounds; $2.5,5.0,7.5$ and $10 \mu \mathrm{g} / \mathrm{mL}$ concentrations for doxorubicin, hence their $\mathrm{IC}_{50}$ values were determined by plotting percentage of inhibition vs. concentration. The DMSO were used as a control.

Sulforhodamine B (SRB) colourimetric assay: The SRB assay [7] is based on the estimation of cellular protein content. The samples were taken in 96-well tissue-culture plate and added $190 \mu \mathrm{L}$ screened ideal cell suspension and mixed occasionally and incubate at $37{ }^{\circ} \mathrm{C}$ with $5 \% \mathrm{CO}_{2}$ and $90 \%$ relative humidity for $3 \mathrm{~h}$. Then add $100 \mu \mathrm{L}$ cold trichloro acetic acid to each well and incubate at $4{ }^{\circ} \mathrm{C}$ for $1 \mathrm{~h}$. After that the plates were gently washed using water, dried using blow dryer and air-dried at room temperature. To each completely dried well, add $100 \mu \mathrm{L}$ of $0.057 \%$ SRB solution, kept aside for $30 \mathrm{~min}$ and quickly rinse with $1 \%$ acetic acid. To the dried plate add $200 \mu \mathrm{L}$ of 10 $\mathrm{mM}$ Tris base ( $\mathrm{pH}$ 10.5) solution, shake for $5 \mathrm{~min}$ and measure the $\mathrm{OD}$ at $510 \mathrm{~nm}$. The blank contains only medium while the control has only cancer cells with no test samples. The percentage of growth inhibition was calculated using below formula.

Growth inhibition $(\%)=100-\left(\frac{\text { Absorbance of sample }}{\text { Absorbance of control }}\right) \times 100$

\section{RESULTS AND DISCUSSION}

The compound $\mathbf{1}$ was isolated as a white powder with m.p. $191-192{ }^{\circ} \mathrm{C}$ and UV absorption at $\lambda_{\max } 222$ in ethanol. The positive mode of FT-MS-ESI provided at $m / z 715.00\left[\mathrm{MH}^{+}\right]$, corresponding to a molecular formula of $\mathrm{C}_{38} \mathrm{H}_{34} \mathrm{O}_{14}$ (calcd. for $\mathrm{C}_{38} \mathrm{H}_{34} \mathrm{O}_{14} \mathrm{~m} / z$. 714.68). Its FT-IR showed for the presence of phenol group (3426.57 $\mathrm{cm}^{-1}$ ) and carbonyl group (1646.32 $\mathrm{cm}^{-1}$ ). The ${ }^{1} \mathrm{H}$ and ${ }^{13} \mathrm{C}$ NMR (Table-1) of $\mathbf{1}$ indicated the presence of 5 methyl group protons at $\delta_{\mathrm{H}} 2.09(s, 3 \mathrm{H}), 2.17(s, 3 \mathrm{H}), 2.55$ $(s, 3 \mathrm{H}), 2.62(s, 3 \mathrm{H})$ and $2.69(s, 3 \mathrm{H})$, with carbon signals at $\delta_{\mathrm{C}} 9.39$ (C-34), 23.46 (C-35), 24.05 (C-33), 25.60 (C-32) and 29.73 (C-38), respectively. The 2 phenolic group protons at $\delta_{\mathrm{H}} 12.50(s, 1 \mathrm{H})$ and $12.55(s, 1 \mathrm{H})$, with carbons at $\delta_{\mathrm{C}} 156.95$ (C-12) and 169.71 (C-4), respectively and 2 aldehyde group protons at $\delta_{\mathrm{H}} 10.36(s, 1 \mathrm{H})$ and $11.95(s, 1 \mathrm{H})$, with carbon signals at $\delta_{\mathrm{C}} 182.41(\mathrm{C}-37)$ and $193.86(\mathrm{C}-30)$, respectively. The ${ }^{1} \mathrm{H}$ NMR spectrum also revealed the presence of aromatic protons at $\delta_{\mathrm{H}} 6.41(s, 2 \mathrm{H}), 6.52(s, 2 \mathrm{H})$ and $6.70-6.72(d d, 2 \mathrm{H})$, with carbon signals at $\delta_{\mathrm{C}} 104.13(\mathrm{C}-5), 96.78$ (C-13), 152.00 (C10), 92.08 (C-20), 112.87 (C-23) and $139.89(\mathrm{C}-26)$. The ${ }^{1} \mathrm{H}$ NMR spectrum also depicted the existence of 3 methoxy at $\delta_{\mathrm{H}}$ $3.90(\mathrm{~s}, 3 \mathrm{H}), 3.93(\mathrm{~s}, 3 \mathrm{H})$ and $4.02(\mathrm{~s}, 3 \mathrm{H})$ with carbon signals at $\delta_{\mathrm{C}} 52.36(\mathrm{C}-29), 55.72(\mathrm{C}-31)$ and 55.67 (C-36), respectively, including 6 carbonyl signals were observed at $\delta_{\mathrm{C}} 165.82$ (C21), 167.50 (C-7), 169.10 (C-14), 172.22 (C-28), 182.41 (C37), 193.86 (C-30).

The HMBC correlations (Fig. 2) revealed the relation between methyl protons at 32-H depicted correlation with C-1 \& C-6, hence the placement of methyl group was confirmed at $\mathrm{C}-6$ position as there is no possibility at C-1. Similarly, the methyl protons at $38-\mathrm{H}$ also showed cross peaks with C-27 \& $\mathrm{C}-26$, which indicates the most possibility of methyl group at C-27 because of depisde correlation observed in C-6. Moreover, the methyl protons at $34-\mathrm{H}$ showed strong cross peaks with C-16 \& C-15 which justifies the presence of methyl group at $\mathrm{C}-16$ position due to lack of possibility at $\mathrm{C}-15$ and the 33 $\mathrm{H}$ showed cross peaks with C-9, which proves the presence of methyl group at C-9. In addition, the methoxy protons at 29$\mathrm{H}$ depicted correlation with $\mathrm{C}-28$, which indicates the presence of benzoate at C-25. Hence, the HMBC correlations were consistent with a rigid structure for $\mathbf{1}$. Furthermore, the complete confirmation is attained by GC-MS analysis of basic hydrolyzed $\mathbf{1}$.

The basic hydrolysis of $\mathbf{1}$ (Scheme-I) was analyzed by GC-MS showed four peaks at retention time 10.981, 16.271, 24.024 and $35.166 \mathrm{~min}$, which were corresponding to $\mathrm{m} / \mathrm{z}$ values of 194, 196, 210 and 168 respectively. Hence, from the GC-MS analysis the four components were confirmed as $\mathbf{1 a}\left(\mathrm{C}_{10} \mathrm{H}_{10} \mathrm{O}_{5}\right.$, 3-formyl-4-hydroxy-2-methoxy-6-methylbenzoic acid) with $\mathrm{m} / \mathrm{z} 210.19[\mathrm{M}]^{+}, \mathbf{1 b}\left(\mathrm{C}_{8} \mathrm{H}_{8} \mathrm{O}_{4}, 2\right.$,4-dihydroxy-5-methylbenzoic acid) with $m / z$ 168.15 [M] $]^{+}, \mathbf{1 c}\left(\mathrm{C}_{10} \mathrm{H}_{12} \mathrm{O}_{4}, 4\right.$-hydroxy-6-methoxy2,3-dimethylbenzoic acid) with $\mathrm{m} / \mathrm{z}, 196.20[\mathrm{M}]^{+}$and $\mathbf{1 d}\left(\mathrm{C}_{10} \mathrm{H}_{10} \mathrm{O}_{4}\right.$,

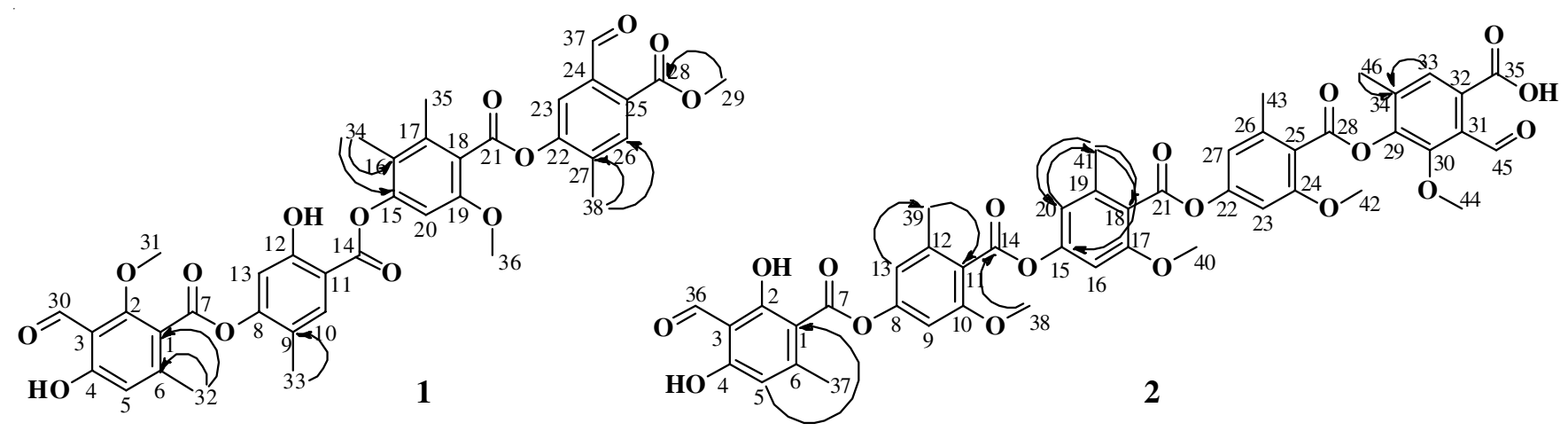

Fig. 2. HMBC correlations of compounds $\mathbf{1}$ and $\mathbf{2}$ 


\begin{tabular}{|c|c|c|c|c|c|c|}
\hline \multirow{3}{*}{ Carbon No. } & \multicolumn{5}{|c|}{$\begin{array}{r}\text { TABLE-1 } \\
\text { TA AND HMBC }\end{array}$} & \\
\hline & \multicolumn{3}{|c|}{ Compound $1 \mathrm{NMR}$ data $\left(400 \mathrm{MHz}, \mathrm{CDCl}_{3}\right)$} & \multicolumn{3}{|c|}{ Compound 2 NMR data $\left(400 \mathrm{MHz}, \mathrm{CDCl}_{3}\right)$} \\
\hline & ${ }^{1} \mathrm{H}$ & ${ }^{13} \mathrm{C}$ & HMBC & ${ }^{1} \mathrm{H}$ & ${ }^{13} \mathrm{C}$ & HMBC \\
\hline 1 & - & 102.85 & $\mathrm{C}-6, \mathrm{C}-32$ & - & 96.77 & $\mathrm{C}-5$ \\
\hline 2 & - & 163.74 & - & $12.50(s, 1 \mathrm{H})$ & 167.49 & - \\
\hline 3 & - & 98.47 & - & - & 98.47 & - \\
\hline 4 & $12.55(s, 1 \mathrm{H})$ & 169.71 & - & $12.55(s, 1 \mathrm{H})$ & 165.82 & - \\
\hline 5 & $6.41(s, 1 \mathrm{H})$ & 104.13 & - & $6.40(s, 1 \mathrm{H})$ & 102.12 & $\mathrm{C}-1$ \\
\hline 6 & - & 152.45 & $\mathrm{C}-1, \mathrm{C}-32$ & - & 152.45 & - \\
\hline 7 & - & 167.50 & - & - & 169.09 & - \\
\hline 8 & - & 163.77 & - & - & 156.95 & - \\
\hline 9 & - & 110.28 & C-33 & $6.67-6.69(d d, 1 \mathrm{H})$ & 92.07 & - \\
\hline 10 & $6.52(s, 1 \mathrm{H})$ & 152.00 & - & - & 159.42 & - \\
\hline 11 & - & 108.56 & - & - & 112.86 & C-39 \\
\hline 12 & $12.50(s, 1 \mathrm{H})$ & 156.95 & - & - & 130.02 & - \\
\hline 13 & $6.41(s, 1 \mathrm{H})$ & 96.78 & - & $6.30-6.34(d d, 1 \mathrm{H})$ & 104.12 & C-39 \\
\hline 14 & - & 169.10 & - & - & 163.77 & C-38 \\
\hline 15 & - & 162.89 & C-16, C-34 & - & 156.95 & C-41 \\
\hline 16 & - & 116.80 & $\mathrm{C}-15, \mathrm{C}-34$ & $6.67-6.69(d d, 1 \mathrm{H})$ & 92.07 & - \\
\hline 17 & - & 143.47 & - & - & 159.42 & - \\
\hline 18 & - & 110.53 & - & - & 112.86 & C-41 \\
\hline 19 & - & 159.42 & - & - & 130.02 & - \\
\hline 20 & $6.52(s, 1 \mathrm{H})$ & 92.08 & - & $6.30-6.34(d d, 1 \mathrm{H})$ & 104.12 & C-41 \\
\hline 21 & - & 165.82 & - & - & 163.77 & - \\
\hline 22 & - & 163.77 & - & - & 156.95 & - \\
\hline 23 & $6.70-72(t, 1 \mathrm{H})$ & 112.87 & - & $6.67-6.69(d d, 1 \mathrm{H})$ & 92.07 & - \\
\hline 24 & - & 112.96 & - & - & 159.42 & - \\
\hline 25 & - & 115.46 & - & - & 112.86 & - \\
\hline 26 & $6.70-72(t, 1 \mathrm{H})$ & 139.89 & $\mathrm{C} 27, \mathrm{C}-38$ & - & 130.02 & - \\
\hline 27 & - & 116.03 & $\mathrm{C}-26, \mathrm{C} 38$ & $6.30-6.34(d d, 1 \mathrm{H})$ & 104.12 & - \\
\hline 28 & - & 172.22 & C- 29 & - & 162.88 & - \\
\hline 29 & $3.90(s, 3 \mathrm{H})$ & 52.36 & $\mathrm{C}-28$ & - & 143.47 & - \\
\hline 30 & $11.95(s, 1 \mathrm{H})$ & 193.86 & - & - & 152.45 & - \\
\hline 31 & $3.93(s, 3 \mathrm{H})$ & 55.72 & - & - & 115.45 & - \\
\hline 32 & $2.62(s, 3 \mathrm{H})$ & 25.60 & C-1, C-6 & - & 115.80 & - \\
\hline 33 & $2.55(s, 3 \mathrm{H})$ & 24.05 & C-9 & $6.52(s, 1 \mathrm{H})$ & 115.28 & C-34 \\
\hline 34 & $2.09(s, 3 \mathrm{H})$ & 9.39 & C-15, C-16 & - & 116.03 & C-33, C-46 \\
\hline 35 & $2.17(s, 3 \mathrm{H})$ & 23.46 & - & $13.39(s, 1 \mathrm{H})$ & 167.49 & - \\
\hline 36 & $4.02(s, 3 \mathrm{H})$ & 55.67 & - & $11.95(s, 1 \mathrm{H})$ & 193.86 & - \\
\hline 37 & $10.36(s, 1 \mathrm{H})$ & 182.41 & - & $2.55(s, 3 \mathrm{H})$ & 29.71 & - \\
\hline 38 & $2.69(s, 3 \mathrm{H})$ & 29.73 & $\mathrm{C}-26, \mathrm{C}-27$ & $3.87(s, 1 \mathrm{H})$ & 52.34 & C-14 \\
\hline 39 & - & - & - & $2.85(s, 3 \mathrm{H})$ & 23.44 & $\mathrm{C}-11, \mathrm{C}-13$ \\
\hline 40 & - & - & - & $3.90(s, 3 \mathrm{H})$ & 55.64 & - \\
\hline 41 & - & - & - & $2.69(s, 3 \mathrm{H})$ & 25.57 & C- $15, \mathrm{C}-18, \mathrm{C}-20$ \\
\hline 42 & - & - & - & $3.90(s, 3 \mathrm{H})$ & 55.70 & - \\
\hline 43 & - & - & - & $2.85(s, 3 \mathrm{H})$ & 24.02 & - \\
\hline 44 & - & - & - & $3.99(s, 3 \mathrm{H})$ & 60.59 & - \\
\hline 45 & - & - & - & $10.36(s, 1 \mathrm{H})$ & 182.42 & - \\
\hline 46 & - & - & - & $2.09(s, 3 \mathrm{H})$ & 9.36 & C-34 \\
\hline
\end{tabular}

methyl 2-formyl-4-hydroxy-5-methylbenzoate) with $\mathrm{m} / z 194.19$ $[\mathrm{M}]^{+}$in NIST library. Based on the correlations from NMR, Mass, HMBC and GC-MS spectral analysis, the linkage of the components of 1 was established and the structure and absolute configuration of 1 was assigned as 4-((4-((5-formyl-4-(methoxycarbonyl)-2-methylphenoxy)carbonyl)-5-methoxy-2,3dimethylphenoxy)carbonyl)-5-hydroxy-2-methylphenyl-3formyl-4-hydroxy-2-methoxy-6-methylbenzoate.

The compound 2 was isolated as a white powder with m.p. $203-204{ }^{\circ} \mathrm{C}$ and UV absorption at $\lambda_{\max } 219$ in ethanol. The positive mode of FT-MS-ESI provided at $\mathrm{m} / z 881.21\left[\mathrm{MH}^{+}\right]$ (calc. for $\mathrm{C}_{46} \mathrm{H}_{40} \mathrm{O}_{18} \mathrm{~m} / z$ is 880.81 ), corresponding to a molecular formula of $\mathrm{C}_{46} \mathrm{H}_{40} \mathrm{O}_{18}$.
The ${ }^{1} \mathrm{H}$ and ${ }^{13} \mathrm{C}$ NMR of 2 (Table-1) indicated the presence of 5 methyl group protons at $\delta_{\mathrm{H}} 2.09(s, 3 \mathrm{H}), 2.55(s, 3 \mathrm{H})$, $2.69(s, 3 \mathrm{H})$ and $2.85(s, 6 \mathrm{H})$, with carbon signals at $\delta_{\mathrm{C}} 9.36$ (C-46), 29.71 (C-37), 25.57 (C-41), 23.44 (C-39) and 24.02 $(\mathrm{C}-43)$. The 2 phenolic protons at $\delta_{\mathrm{H}} 12.50(s, 1 \mathrm{H})$ and 12.55 $(s, 1 \mathrm{H})$, with carbon signals at $\delta_{\mathrm{C}} 167.49(\mathrm{C}-2)$ and $165.82(\mathrm{C}-$ $4)$, respectively and 2 aldehyde protons at $\delta_{\mathrm{H}} 10.36(s, 1 \mathrm{H})$ and $11.95(s, 1 \mathrm{H})$, with carbon signals at $\delta_{\mathrm{C}} 182.42(\mathrm{C}-45)$ and 193.86 (C-36), respectively. The 8 aromatic protons at 6.30$6.34(d d, 3 \mathrm{H}), 6.40(s, 1 \mathrm{H}), 6.52(s, 1 \mathrm{H})$ and 6.67-6.69 $(d d, 3 \mathrm{H})$. The 4 methoxy group protons at $3.87(s, 1 \mathrm{H}), 3.90(s, 6 \mathrm{H})$ and $3.99(s, 3 \mathrm{H})$, with carbon signals at $\delta_{\mathrm{C}} 52.34(\mathrm{C}-38), 55.64(\mathrm{C}-$ 40), 55.70 (C-42) and 60.59 (C-44), including 7 carbonyl 
<smiles>COC(=O)c1cc(C)c(OC(=O)c2c(OC)cc(OC(=O)c3cc(C)c(OC(=O)c4c(C)cc(O)c(C=O)c4OC)cc3O)c(C)c2C)cc1ON(C)O</smiles>

Scheme-I: Basic hydrolysis of compound $\mathbf{1}$

signals were observed at $\delta_{\mathrm{C}} 162.88$ (C-28), 163.77 (C-14/21), 167.49 (C-35), 169.09 (C-7), 182.42 (C-45) and 193.86 (C-36).

The HMBC (Fig. 2) confirmed the interaction of aryl protons i.e. 5-H with $\mathrm{C}-1$ (one-two correlation), 13-H with $\mathrm{C}$ 39 , 20-H with $\mathrm{C}-41$ and $33-\mathrm{H}$ with $\mathrm{C}-34$, which confirm the presence of aromatic hydrogen at positions C-5, C-13, C-20 and $\mathrm{C}-33$, respectively. The methoxy protons at $38-\mathrm{H}$ showed cross peaks with $\mathrm{C}-14$ i.e. one-two-three correlation, hence justifies the presence of methoxy group at C-38. Moreover, the methyl protons at $39-\mathrm{H}$ depicted strong cross peaks with $\mathrm{C}-11$ i.e. one-two correlation, which confirms the methyl group at $\mathrm{C}-12$. Furthermore, the methyl protons showed one-three correlation at $41-\mathrm{H}$ with $\mathrm{C}-15, \mathrm{C}-18$ and $\mathrm{C}-20$, hence this support the presence of methyl group at $\mathrm{C}-19$. Likewise, strong correlation from methyl protons at $46-\mathrm{H}$ to $\mathrm{C}-34$ was also noticed, which confirms the presence of methyl group at C-34 (Table-1). In addition, the complete confirmation is attained by GC-MS analysis of basic hydrolyzed 2.

The basic hydrolysis of $\mathbf{2}$ (Scheme-II) was analyzed by GC-MS showed three peaks at retention time 6.141, 21.012 and $61.941 \mathrm{~min}$ which were corresponding to $\mathrm{m} / \mathrm{z}$ values of 182, 210 and 196 respectively. Hence, from the GC-MS analysis the three components were confirmed as $\mathbf{2} \mathbf{a}\left(\mathrm{C}_{9} \mathrm{H}_{8} \mathrm{O}_{5}, 3\right.$-formyl2,4-dihydroxy-6-methylbenzoic acid) with $\mathrm{m} / \mathrm{z}, 196.16[\mathrm{M}]^{+}$, 2b $\left(\mathrm{C}_{9} \mathrm{H}_{10} \mathrm{O}_{4}\right.$, 4-hydroxy-2-methoxy-6-methylbenzoic acid) with $m / z, 182.18[\mathrm{M}]^{+}$and $2 \mathrm{c}\left(\mathrm{C}_{10} \mathrm{H}_{10} \mathrm{O}_{5}, 2\right.$-formyl-4-hydroxy3-methoxy-5-methylbenzoic acid) with $\mathrm{m} / \mathrm{z} 210.19[\mathrm{M}]^{+}$in NIST library. Based on the correlations from NMR, Mass, HMBC and GC-MS spectral analysis, the linkage of the components of $\mathbf{2}$ was established and the structure and absolute configuration of 2 was assigned as 2-formyl-4-((4-)(4-((4-)((3-formyl2,4-dihydroxy-6-methylbenzoyl)oxy)-2-methoxy-6-methylbenzoyl)oxy)-2-methoxy-6-methylbenzoyl)oxy)-2-methoxy6-methylbenzoyl)oxy)-3-methoxy-5-methyl benzoic acid.

Antioxidant activity: Generally, natural antioxidants have great forbearance to humans and are sans of considerable side effects [7]. The inferior $\mathrm{IC}_{50}$ values indicates superior inhibition of free radicals. From the antioxidant results it is confirmed that the 1, 2 and $\mathbf{6}$ depicted to have promising antiradical scavenging capacities. In all the antioxidant assays, the 1, 2 and 6 showed markedly higher radical scavenging activity than other compounds.<smiles>COc1cc(OC(=O)c2c(C)cc(OC(=O)c3c(C)cc(OC(=O)c4c(C)cc(O)c(C=O)c4O)cc3OC)cc2C)cc(C)c1C(=O)Oc1cc(C)c(C(=O)Oc2c(C)cc(C(=O)O)c(C=O)c2OC)c(OC)c1</smiles>

Scheme-II Basic hydrolysis of compound 2

In DPPH radical scavenging assay [9], the antioxidant capable substances are able to reduce the stable purple coloured DPPH radical to a yellow coloured non-radical DPPH-H form. Generally, the DPPH radical quenching activity of antioxidants are ascribed to their hydrogen donating capacities [9]. As shown in Fig. 3, the $\mathrm{IC}_{50}$ value for $\mathbf{1 , 2 , 3 , 4 , 5}$ and $\mathbf{6}$ on $\mathrm{DPPH}$ were calculated to be $30.5,32.0,68.0,53.5,43.0$ and $39.0 \mu \mathrm{g} /$ $\mathrm{mL}$, respectively, while standard drug (ascorbic acid) with 27.0 $\mu \mathrm{g} / \mathrm{mL}$.

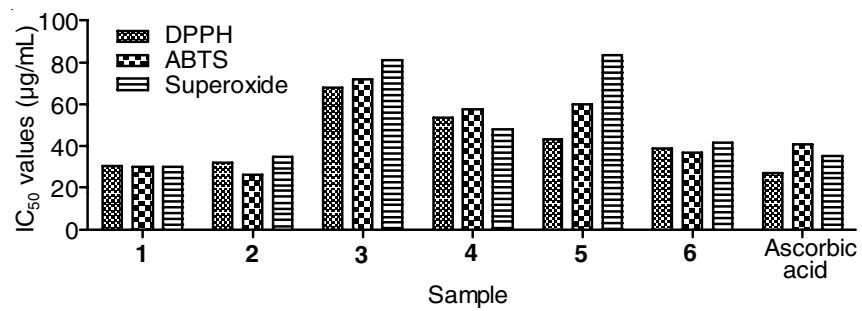

Fig. 3. $\mathrm{IC}_{50}$ values of isolates (1-6) against DPPH, ABTS and Superoxide free radicals

The principal of ABTS radical assay [10] is similar to that of DPPH assay in which decoy of the radical cation $\mathrm{ABTS}^{+\bullet}$ takes place. Among all samples, the isolates 1, 2 and $\mathbf{6}$ showed better $\mathrm{IC}_{50}$ of $30.0,26.0$ and $37.0 \mu \mathrm{g} / \mathrm{mL}$, respectively, than that of the standard $(41.0 \mu \mathrm{g} / \mathrm{mL})$. The $\mathrm{IC}_{50}$ values of $\mathbf{3 , 4}$ and 5 on ABTS radical were noticed to be 72.0, 57.5 and $60.0 \mu \mathrm{g} /$ $\mathrm{mL}$, respectively (Fig. 3).

The superoxide radical generally arise from metabolic process/ROS, which interact with other substrates in presence of enzyme/metal catalyzed processes to generated hydroxyl radical, $\mathrm{H}_{2} \mathrm{O}_{2}$ and ${ }^{1} \mathrm{O}_{2}$. These radicals persuade oxidative damage in DNA, lipids and proteins. From the superoxide free radical assay [9], it was noticed that $\mathbf{1}$ and $\mathbf{2}$ showed better $\mathrm{IC}_{50}$ than that of the standard. The concentration of $\mathbf{1 , 2}, \mathbf{3}, \mathbf{4 ,} 5$ and 6 needed for $50 \%$ inhibition of superoxide radical were found to be $30.0,35.0,81.0,48.0,83.5$ and $41.5 \mu \mathrm{g} / \mathrm{mL}$, respectively, while ascorbic acid was $35.5 \mu \mathrm{g} / \mathrm{mL}$ (Fig. 3). Hence, the higher free radical quenching capabilities of the isolated metabolites may be due to the presence of oxygenated substituents like phenolics and carbonyls in the molecules. 
in vitro Anti-inflammatory activity: The denaturation of biological proteins causes inflammation. The denaturation pathways can be performed by acidic (or) alkaline reactions, heat treatment, radiation reactions, etc. Proteins lose their complex tertiary structure because of the externally induced stress under the above mentioned conditions thus leading to denaturation. Therefore, in the present work the isolates from D. consimilis were tested for inhibition of protein denaturation induced by heat [6]. Among the tested D. consimilis compounds, the compound $\mathbf{4}$ showed better inhibitory profile against protein denaturation with $\mathrm{IC}_{50}$ value of $390 \mu \mathrm{g} / \mathrm{mL}$, which was far better than all other isolates of $D$. consimilis. The $\mathrm{IC}_{50}$ values of compounds $\mathbf{1 , 2}, \mathbf{3}, \mathbf{5}$ and $\mathbf{6}$ on protein denaturation were found to be $878,600,632,922$ and $700 \mu \mathrm{g} / \mathrm{mL}$, respectively, while indomethacin with $110.0 \mu \mathrm{g} / \mathrm{mL}$ (Fig. 4).

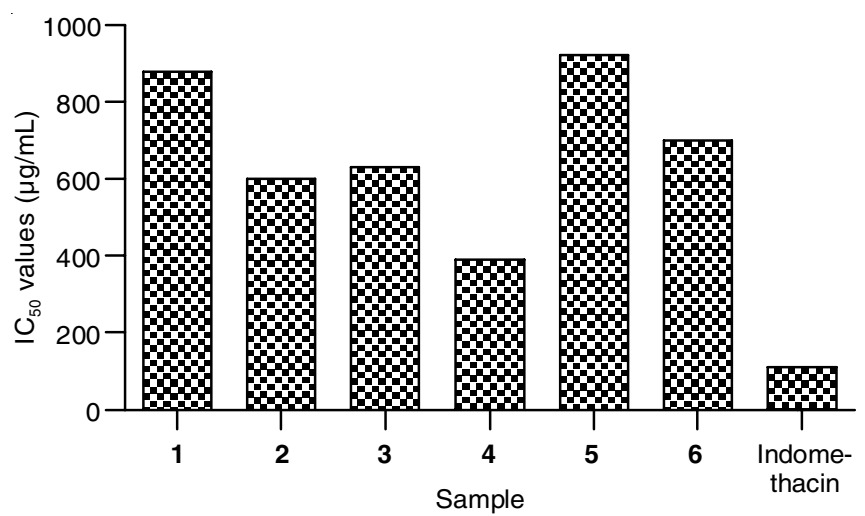

Fig. 4. $\mathrm{IC}_{50}$ values of isolates (1-6) against protein denaturation

Anticancer activity: As chronic inflammation is crucial in many deadly diseases like cancer. In addition, as the isolated metabolites showed good anti-inflammatory potentialities, we have screened the isolated secondary metabolites (2-6) for their anticancer activity by using Sulforhodamine B (SRB) assay [7] and calculated their $\mathrm{IC}_{50}$ values. Initially, the compounds (2-6) at $30 \mu \mathrm{g} / \mathrm{mL}$ concentration were screened against breast (MCF-7), colon (DLD-1), cervical (HeLa), head \& neck (FaDu), lung (A549) and normal human mammary epithelial (NHME) cell lines using SRB assay and standard (doxorubicin, $10 \mu \mathrm{g}$ / $\mathrm{mL}$ ) and the percentage of inhibition of cell growth was tabulated in Table-2. Further, the active samples i.e. more than 50 $\%$ cell death were further screened at $5,10,20$ and $30 \mu \mathrm{g} / \mathrm{mL}$ concentrations for pure compounds; 2.5, 5.0, 7.5 and $10 \mu \mathrm{g}$ / $\mathrm{mL}$ concentrations for doxorubicin. The results are plotted to obtain $\mathrm{IC}_{50}$ values. The lower $\mathrm{IC}_{50}$ value indicates better inhibitory profile against cancer cell lines.
During the initial screening, the isolates 2, 3, 5 and 6 depicted prominent degree of specificity against all the tested cancer cell lines. Besides, all the samples exhibited very low degree of specificity against NHME cell lines indicates they are non-toxic towards normal human cells (Table-2). The preliminary screening results revealed that the compound $\mathbf{2}$ $(30 \mu \mathrm{g} / \mathrm{mL})$ showed better inhibition of cell growth of MCF-7 and HeLa with $83.70 \pm 2.40$ and $90.90 \pm 6.30 \%$ cell growth inhibition, respectively, than the doxorubicin $(10 \mu \mathrm{g} / \mathrm{mL})$ with $81.25 \pm 1.56$ and $85.55 \pm 1.31 \%$ cell death, respectively (Table2 ). Whereas, the $\mathbf{3}$ and $\mathbf{5}$ showed moderate degree of specificity against tested cancer cell lines. On the other hand, the $\mathbf{6}$ showed significant inhibitory profile against MCF-7, DLD-1, HeLa, FaDu and A549 (Table-2).

Considering the initial screening, the active samples i.e. compounds $\mathbf{2}, \mathbf{3}, \mathbf{5}$ and $\mathbf{6}$ were further evaluated of their $\mathrm{IC}_{50}$ values and illustrated in Fig. 5. The compound $\mathbf{2}$ depicted better $\mathrm{IC}_{50}$ values of $11.50 \mu \mathrm{g} / \mathrm{mL}$ on $\mathrm{MCF}-7$ with respect to doxorubicin $(5.50 \mu \mathrm{g} / \mathrm{mL})$, whereas compounds 3 and $\mathbf{6}$ showed $\mathrm{IC}_{50}$ value of about 26.50 and $22.50 \mu \mathrm{g} / \mathrm{mL}$, respectively (Fig. 5). Compounds 2, 3, 5 and $\mathbf{6}$ revealed significant $\mathrm{IC}_{50}$ values of $22.0,15.50,15.0$ and $17.70 \mu \mathrm{g} / \mathrm{mL}$, respectively on DLD-1, while doxorubicin with $5.4 \mu \mathrm{g} / \mathrm{mL}$. Based on the SRB assay results of $\mathrm{HeLa}$, it is observed that the $\mathrm{IC}_{50}$ values of tested compounds on HeLa were found to be in the order doxorubicin $(4.5 \mu \mathrm{g} / \mathrm{mL})<\mathbf{2}(10.5 \mu \mathrm{g} / \mathrm{mL})<\mathbf{3}(16.5 \mu \mathrm{g} / \mathrm{mL})<\mathbf{5}(17.5 \mu \mathrm{g} /$ $\mathrm{mL})<\mathbf{6}(18.5 \mu \mathrm{g} / \mathrm{mL})$ (Fig. 5). Similarly, it is noticed that the concentration of 2, 3, 5 and $\mathbf{6}$ needed for $50 \%$ inhibition of FaDu were found to be $12.5,14.519 .0$ and $21.0 \mu \mathrm{g} / \mathrm{mL}$, respectively, whereas doxorubicin with $3.8 \mu \mathrm{g} / \mathrm{mL}$ (Fig. 5). From the obtained data, it can be confirmed that the only compounds

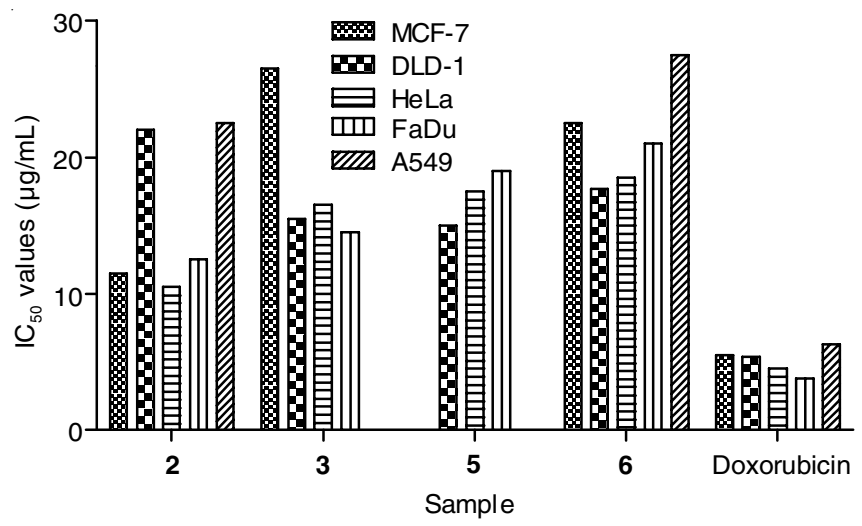

Fig. 5. $\mathrm{IC}_{50}$ of isolates (1-6) against test panel of cell lines

TABLE-2

PERCENTAGE OF INHIBITION AND IC I0 $_{5}$ VALUES OF ISOLATES (2-6)

AGAINST SERIES OF CANCER CELL LINES AND NHME CELL LINE

\begin{tabular}{ccccccc}
\hline \multirow{2}{*}{ Sample } & \multicolumn{5}{c}{ Percentage inhibition $(\%)$ at $30 \mu \mathrm{g} / \mathrm{mL}$ concentration* } \\
\cline { 2 - 7 } & MCF-7 & DLD-1 & HeLa & FaDu & A549 & NHME \\
\hline $\mathbf{2}$ & $83.70 \pm 2.40$ & $67.60 \pm 7.90$ & $90.90 \pm 6.30$ & $89.70 \pm 6.80$ & $66.50 \pm 3.20$ & $8.07 \pm 0.60$ \\
$\mathbf{3}$ & $56.21 \pm 1.09$ & $77.19 \pm 0.57$ & $75.89 \pm 1.77$ & $78.89 \pm 5.82$ & $40.75 \pm 2.20$ & $7.19 \pm 0.45$ \\
$\mathbf{4}$ & $10.91 \pm 1.24$ & $7.80 \pm 1.15$ & $2.55 \pm 0.79$ & $7.01 \pm 0.93$ & $8.68 \pm 1.53$ & $1.82 \pm 0.46$ \\
$\mathbf{5}$ & $44.95 \pm 3.42$ & $72.23 \pm 3.20$ & $70.17 \pm 1.19$ & $74.83 \pm 4.01$ & $30.78 \pm 3.15$ & $4.51 \pm 0.73$ \\
$\mathbf{6}$ & $64.69 \pm 5.26$ & $77.21 \pm 1.06$ & $73.97 \pm 3.44$ & $71.04 \pm 2.38$ & $55.82 \pm 3.20$ & $6.66 \pm 1.33$ \\
Doxorubicin** & $81.25 \pm 1.56$ & $72.67 \pm 0.21$ & $85.55 \pm 1.31$ & $98.50 \pm 1.21$ & $77.92 \pm 0.41$ & $1.20 \pm 0.81$ \\
\hline
\end{tabular}

$* \mathrm{n}=3 ;$ Mean $\pm \mathrm{SD} ; * * 10 \mu \mathrm{g} / \mathrm{mL}$ 
$\mathbf{2}$ and $\mathbf{6}$ are active against $\mathrm{A} 549$ with $\mathrm{IC}_{50}$ values of 22.5 and $27.5 \mu \mathrm{g} / \mathrm{mL}$, respectively, while doxorubicin with $6.3 \mu \mathrm{g} / \mathrm{mL}$ (Fig. 5).

Hence, form the SRB analysis it can be concluded that the key agents responsible for the anticancer activity of $D$. consimilis were $\mathbf{2}, \mathbf{3}, \mathbf{5}$ and $\mathbf{6}$. Furthermore, the low toxicity against NHME indicates that all the compounds are less toxic towards normal human cells. Hence, these active metabolites can be a benchmarks for designing potent anticancer agents.

\section{Conclusion}

In conclusion, we have established the chemical and pharmacological profile of manglicolous lichen $D$. consimilis by using standard methods. The chemical examination of the acetone extract revealed the presence of two new metabolites (1 \& 2) along with four known metabolites (3-6). The pharmacological evaluation of the pure isolated compounds (1-6) showed prominent inhibition of DPPH, ABTS, superoxide free radicals, protein denaturation, MCF-7, DLD-1, HeLa, FaDu and A549 cancer cell lines. This study confirms the biological importance of $D$. consimilis as a good source for antioxidants, anti-inflammatory and anticancer agents.

\section{ACKNOWLEDGEMENTS}

The authors are thank full to the Ministry of Earth Sciences (Grant number: MOES-2/DS/6/2017), India for the financial support.

\section{CONFLICT OF INTEREST}

The authors declare that there is no conflict of interests regarding the publication of this article.

\section{REFERENCES}

1. R. Valarmathi, G.N. Hariharan, G. Venkataraman and A. Parida, Phytochemistry, 70, 721 (2009);

https://doi.org/10.1016/j.phytochem.2009.04.007.

2. E.F. Ahmed, W.A. Elkhateeb, H.A.A. Taie, M.E. Rateb and W. Fayad, J. Appl. Pharm. Sci., 7, 098 (2017); https://doi.org/10.7324/JAPS.2017.70113.

3. M.W. Samdudin, H. Azahar, A. Abas and Z. Zakaria, J. Environ. Prot., 4, 760 (2013);

https://doi.org/10.4236/jep.2013.48088.

4. X. Huang, L. Wang, A.K.C. Laserna and S.F.Y. Li, Metallomics, 9, 1610 (2017);

https://doi.org/10.1039/C7MT00207F.

5. J. Kang, R.Y. Chen and D.Q. Yu, J. Asian Nat. Prod. Res., 7, 729 (2005); https://doi.org/10.1080/1028602042000324943.

6. V.B. Tatipamula and G.S. Vedula, J. Biomed. Sci., 4, 3 (2018); https://doi.org/10.3126/jbs.v4i1.20572.

7. V.B. Tatipamula and G.S. Vedula, Hygeia. J. Dent. Med., 10, 16 (2018); https://doi.org/10.15254/H.J.D.Med.10.2018.174.

8. T.V. Bharadwaj, V.G. Sastry and K.S. Murthy, Studies in Fungi, 3, 302 (2018).

9. V.B. Tatipamula, K.N. Killari, V.G. Sastry and A. Ketha, Bangladesh J. Pharmacol., 12, 16 (2017); https://doi.org/10.3329/bjp.v12i2.31764.

10. S.J. Hwang, W.B. Yoon, O.H. Lee, S.J. Cha and J.D. Kim, Food Chem., 146, 71 (2014); https://doi.org/10.1016/j.foodchem.2013.09.035.

11. A. Yashin, Y. Yashin, X. Xia and B. Nemzer, Antioxidants, 6, E70 (2017); https://doi.org/10.3390/antiox6030070. 